\title{
A MULTIDISCIPLINARY APPROACH TO THE ATTAWAPISKAT KIMBERLITE FIELD, CANADA: ACCELERATING THE DISCOVERY TO PRODUCTION PIPELINE
}

\author{
N. Januszczak ${ }^{1}$, M.H. Seller ${ }^{1}$, S. Kurszlaukis ${ }^{1}$, C. Murphy ${ }^{1}$, J. Delgaty ${ }^{1}$, S. Tappe ${ }^{2}, K$. Ali ${ }^{1}$, J. Zhu ${ }^{1}$, and P. \\ Ellemers 1 \\ ${ }^{1}$ De Beers Canada Inc., Toronto, Canada, \\ ${ }^{2}$ Westfälische Wilhelms-Universität, Münster, Germany
}

\section{INTRODUCTION}

The Attawapiskat kimberlite field is located in the James Bay Lowlands of northern Ontario, approximately 90 $\mathrm{km}$ west of the coastal community of Attawapiskat First Nation (Fig. 1). Within the Attawapiskat kimberlite field, Victor Mine is one of 23 kimberlite pipes discovered, 21 of which have been tested for diamonds with all reporting positive results. It is Ontario's first diamond mine and the second in Canada for De Beers.

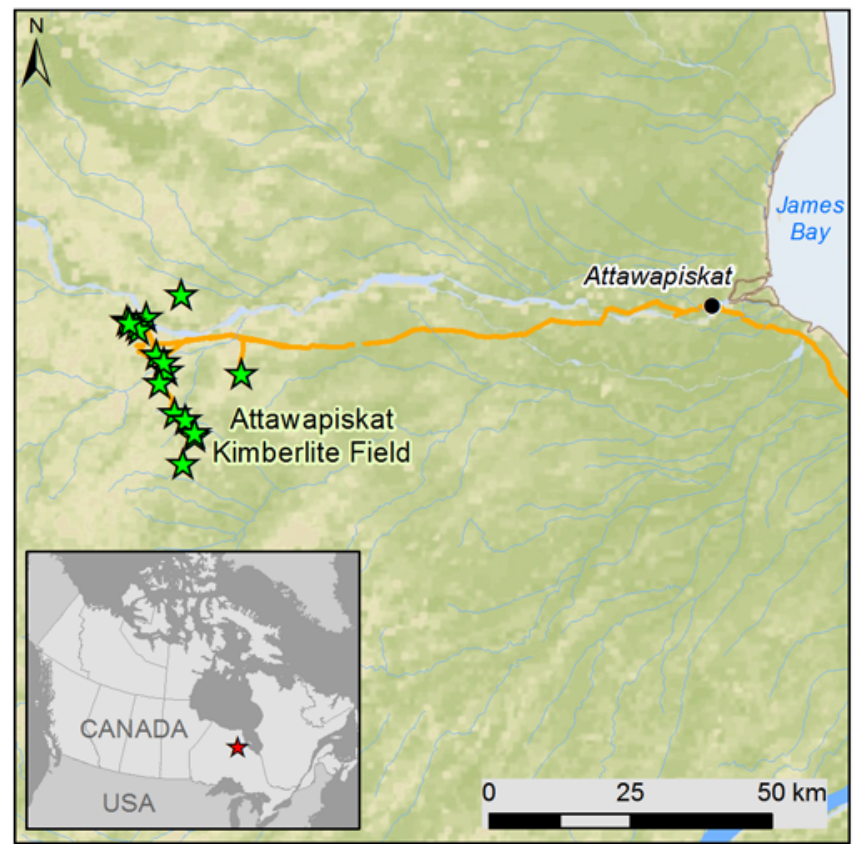

Figure 1. The Attawapiskat kimberlite field is located within the James Bay Lowlands of Ontario, Canada. Temporary coastal and Attawapiskat to Victor Mine winter roads are shown in orange.
Victor mine has a 10 year mine life with potential for extension from additional kimberlite resources sourced from its satellite pipes. Victor is approximately 15 hectares in size and has a variable grade averaging 0.25 carats per tonne. With an average rough diamond value of over 440 USD per carat, the value of the ore at Victor is comparable to other world-class diamond producers.

\section{DISCOVERY}

Broad regional sampling was conducted in the Attawapiskat region of the James Bay Lowlands in the 1960s. Follow up stream sampling was conducted in 1987 to validate sampling anomalies and kimberlite boulders were discovered along the Attawapiskat River. Airborne magnetic data at $250 \mathrm{~m}$ line spacing and $100 \mathrm{~m}$ mean terrain clearance was acquired later that same year. The initial discovery of the Victor kimberlite and 15 satellite pipes occurred in 1988 and 1989 from drilling of high interest geophysical targets. Additional discoveries were made in 1995, 2001, and 2004. Two additional pipes were discovered in 2009 from detailed $75 \mathrm{~m}$ line spacing airborne magnetic data.

A decade after the discovery of the Attawapiskat kimberlite field, testing of drill core and reviews of available data motivated for a small bulk sample program on the Victor kimberlite in 1997. Twenty tonnes of kimberlite material were collected using a reverse circulation (RC) rig. Seven carats of diamonds were recovered which were unusually and uniquely coarse in their size frequency distribution. These results motivated for a larger program in 1999 to obtain sufficient stones for initial valuation; this and subsequent sampling programs revealed the value of the resource contained within the Victor kimberlite. Approval to build Victor mine was given in 2005 and commercial production began in 2008 . 


\section{$10^{\text {th }}$ International Kimberlite Conference, Bangalore - 2012}

\section{Kimberlite Characteristics}

All but one of the Attawapiskat kimberlite pipes exhibit high amplitude positive magnetic profiles (Fig. 2). High resolution magnetic data has proven very effective for target generation in the magnetically quiet Paleozoic carbonate bedrock. In addition, petrophysics has proven very useful for the purpose of evaluating the utility of various geophysical techniques. Portions of the pipes exhibit prominent gravity highs, gravity lows or are gravity neutral. As carbonate bedrock bioherms exhibit prominent gravity anomalies, the use of gravity can be challenging. Limited conductivity contrast between kimberlite and Paleozoic carbonate bedrock hinders the use of electromagnetic techniques for drill target generation, thus an integrated approach is required to generate and prioritize geophysical anomalies. Both electromagnetic and gravity techniques have been critical for understanding internal kimberlite geology and have aided in generating three dimensional models of the kimberlites.
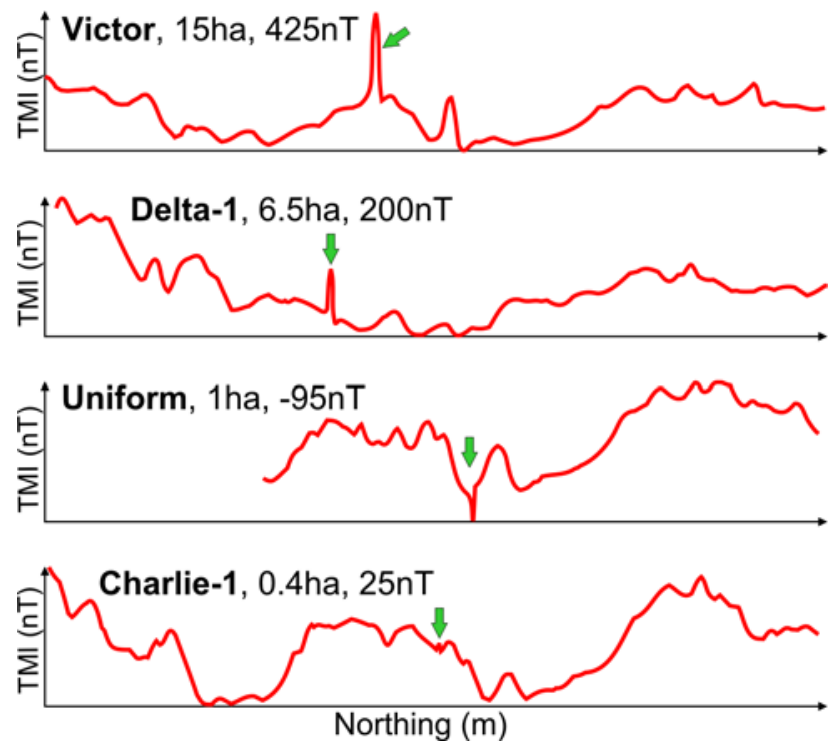

Figure 2. Magnetic response from the discovery survey of four kimberlites within the Attawapiskat kimberlite field. Uniform is the only kimberlite that exhibits a negative magnetic anomaly.

The garnet chemistry of the kimberlites is lherzolitedominated (Fig. 3) and initial microdiamond results from discovery drill holes were not encouraging. Shortly after the discovery of the Attawapiskat kimberlite field, the discovery of kimberlites with harzburgite-dominated garnet chemistry similar to that observed in economic diamond deposits in southern Africa resulted in a "diamond rush" in the Lac de Gras region of the Northwest Territories. Focus shifted away from the seemingly low interest results in the Attawapiskat kimberlite field.

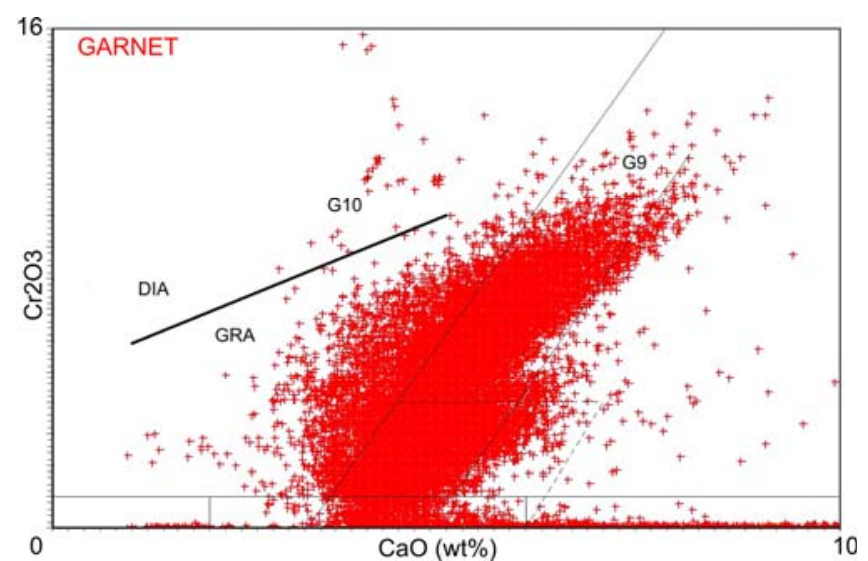

Figure 3. Major element garnet chemistry for all of the Attawapiskat kimberlites (after Grutter et al., 2004 and Grutter and Sweeney, 2000).

The Attawapiskat kimberlites are middle Jurassic in age (174-179 Ma, U-Pb perovskite ages). It is critical to obtain high precision $\mathrm{U}-\mathrm{Pb}$ perovskite ages for as many pipes as possible to see if a relationship exists between the age of emplacement and diamond quantity and quality. However, finding suitable groundmass perovskite for geochronology purposes is challenging in the Attawapiskat kimberlite field. There are currently few pipes for which high confidence age determinations exist which hamper a conclusive integration of age data with diamond characteristics.

Emplacement of kimberlite magmas in the Attawapiskat area during the middle Jurassic is coincident with an extensional tectonic regime in eastern North America associated with the rifting of Pangea and opening of the North Atlantic (Heaman et al., 2003). At that time, rifting along the eastern margin of Laurentia had commenced. Widespread igneous activity in eastern North America is recorded in the emplacement of kimberlites and related rocks, and the reactivation of faults and grabens (Tappe et al., 2007; Heaman et al., 2003; Zentilli et al., 2001, Glasmacher et al., 1998).

The kimberlite pipes are emplaced into flat-lying Ordovician and Silurian sedimentary rocks which unconformably overlie granodiorite and granitic rocks of the 2.7 Ga Oxford Stull Domain within the Archean Superior Craton (Fig. 4; Thurston et al., 1991; Corkery et al., 2000). The thickness of the Paleozoic strata in the area is approximately $275 \mathrm{~m}$. It is estimated that approximately $200 \mathrm{~m}$ of cover rocks have been eroded based on the presence of Devonian xenoliths recovered from kimberlites now hosted within middle Silurian Attawapiskat Formation limestones and dolostones (F. Brunton pers. comm.; Fig. 4). 


\section{$10^{\text {th }}$ International Kimberlite Conference, Bangalore - 2012}

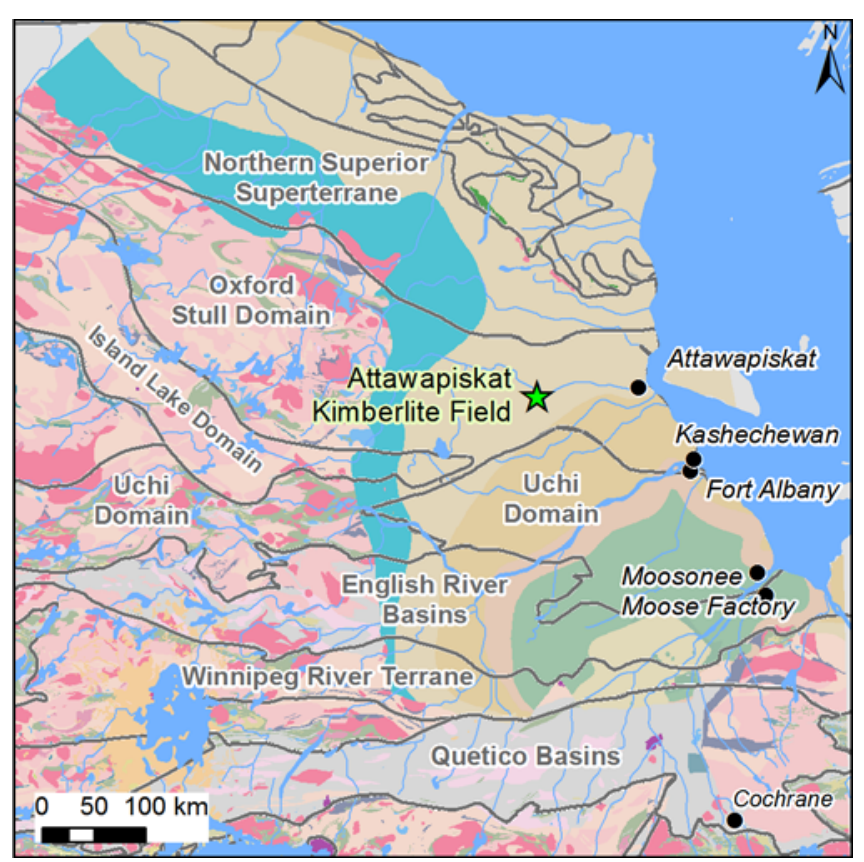

Figure 4. Archean domains and extent of Paleozoic carbonate bedrock in the vicinity of the Attawapiskat kimberlite field (blue: Ordovician; light brown: Silurian; dark brown: Devonian; green: Cretaceous) (after Wheeler et al., 1996).

The pipes vary in size from less than a hectare to 17 hectares. Their morphologies and locations are influenced by major basement structures that have been reactivated as evidenced in geophysical and remotely sensed imagery. The kimberlites within the kimberlite field trend northwest along a regional Matachewan mafic dyke system (c. 2.45 $\mathrm{Ga}$; Stott and Josey, 2009). Locally, the shapes of individual pipes are influenced by the presence of Matachewan, Marathon, and Biscotasing dyke systems (c. 2.1 to $2.2 \mathrm{Ga}$; Stott and Josey, 2009) and localized brittle faulting (Fig. 5).
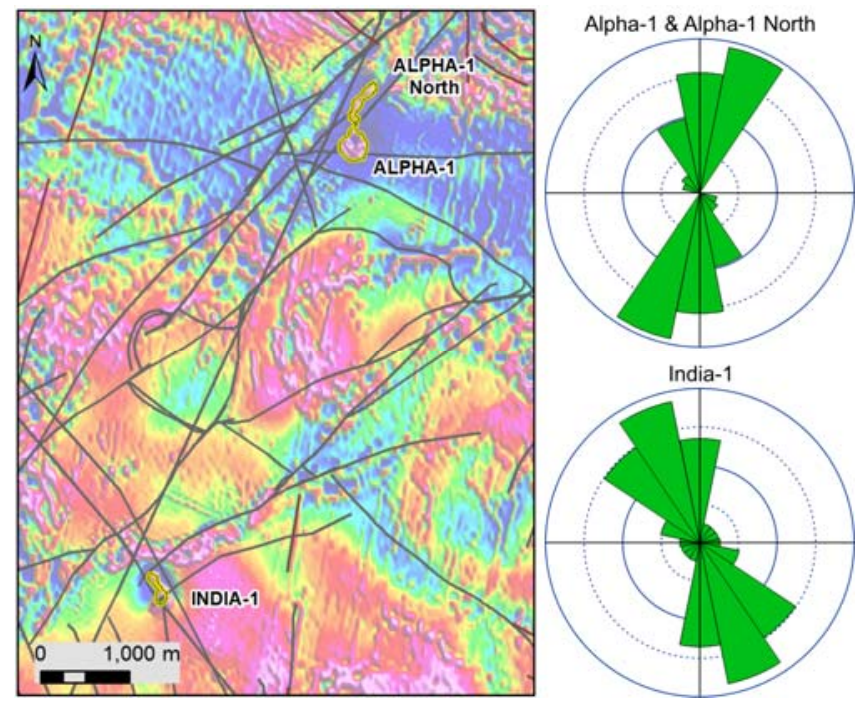

Figure 5. Mafic dykes and faults mapped in the immediate vicinity of the Alpha-1, Alpha-1 North and India-1 kimberlites. Trends of proximal lineaments mirror the morphology of the kimberlites.

\section{INDICATOR DISPERSION}

Post-glacial inundation of the Tyrrell Sea and deposition of marine clays has resulted in the formation of extensive wetlands characteristic of the James Bay Lowlands (Dredge and Cowan, 1989). Although highly variable within the kimberlite field, the typical overburden profile is kimberlite overlain by metres of clay-rich till, followed by metres of massive marine clay and topped with over a metre of muskeg. Sampling effectiveness in this terrain is poor. Quaternary sediment cover thickness within the Attawapiskat kimberlite field is variable ranging from 0 $\mathrm{m}$ to $40 \mathrm{~m}$. Striations preserved on kimberlite and clast fabric from till sections exposed along local rivers indicate an older south southeast ice flow overprinted by a younger southwest directed ice flow (Fig. 6). Clast fabrics for both the lower and upper till units exhibit strong unimodal distribution suggesting deposition by lodgement processes. Locally, clasts exhibit multimodal fabrics indicative of deformation processes (Hart, 1994).

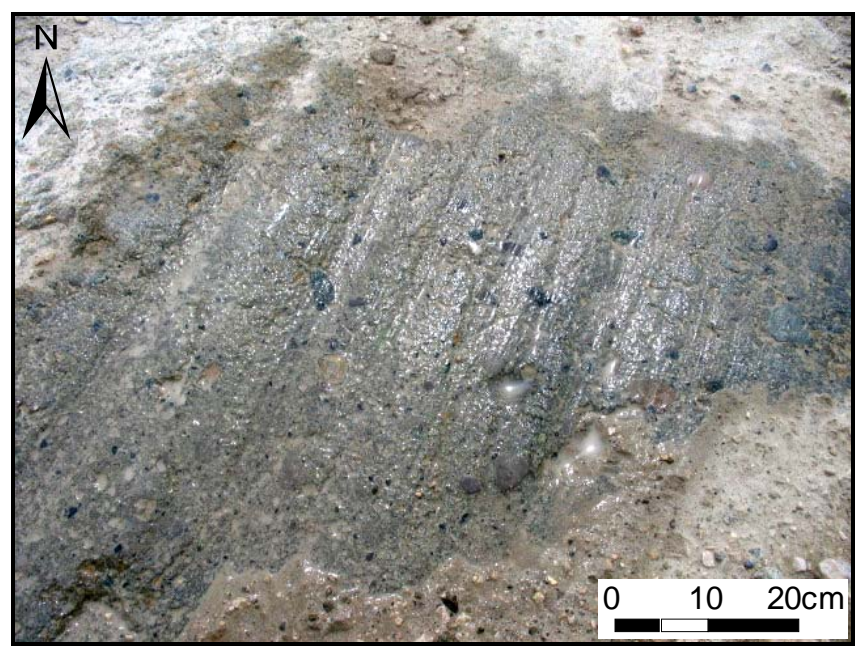

Figure 6. Striations preserved on the Victor kimberlite recording late-stage southwest ice flow.

Seasonal river ice plays a significant role in concentrating heavy minerals sourced from till excavated along the banks of large first order rivers. These Pleistocene and Recent processes, in part, explain indicator mineral dispersion observed in the area.

\section{KIMBERLITE EMPLACEMENT}

The pipes within the Attawapiskat kimberlite field have undergone complex emplacement processes (e.g., vent migration during emplacement) and the resultant internal geology is highly variable. The re-use of existing plumbing 
systems over time has led to complex amalgamated crater fields. Individual kimberlite pipes are compositionally distinct as are some facies within pipes. Mantle sampling profiles derived from garnet trace element data are highly variable between pipes and within pipes. High grade ore at Victor is characterized by predominantly unimodal mantle sampling focused within the diamond stability field.

Mineral composition in combination with whole-rock chemical composition, petrology and various petrophysical data are used to characterize distinct internal geological units and develop three dimensional geological models. Three dimensional geological models are further constrained by various geophysical inversion and magnetotelluric techniques. As diamond content and value varies between geologic units, a robust geological model is required to design and execute a representative bulk sampling program.

\section{References}

Corkery, M.T., Cameron, H.D. M., Lin, S., Skulski, T., Whalen, J.B., and Stern, R.A., 2000. Geological Investigations in the Knee Lake Belt (Parts of NTS 53L). Manitoba Industry, Trade and Mines, Manitoba, Geological Survey, Report of Activities 2000, 7 p.

Dredge, L.A., and Cowan, W.R., 1989. Quaternary geology of the southwestern Canadian Shield. In Quaternary Geology of Canada and Greenland. R.J., Fulton (Ed.). Geological Survey of Canada, p. 214-249.

Glasmacher, U., Tremblay, A., Zentilli, M., 1998. Post-Triassic thermo-tectonic evolution of the Laurentian margin in Québec, Canada. Abstracts Geological Association of Canada Meeting, Québec City 23, A-66.

Grütter, H.S, and Sweeney, R., 2000. Tests and constraints on single-grain Cr-pyrope barometer models: some initial results. GEOCANADA 2000 Extended Abstracts, University of Calgary.

Grutter, H.S., Gurney, J.J., Menzies, A.H., and Winter, F., 2004. An updated classification scheme for mantle-derived garnet, for use by diamond explorers. Lithos, 77, p. 841-857.

Hart, J.K., 1994. Till fabric associated with deformable beds. Earth Surface Processes and Landforms, 19, p. 15-32.

Heaman, L.M., Kjarsgaard, B.A., and Creaser, R.A., 2003. The timing of kimberlite magmatism in North America: implications for global kimberlite genesis and diamond exploration. Lithos, 71, p. $153-184$.

Thurston, P.C., Osmani, I.A., and Stone, D. 1991. Northwestern Superior Province: Review and terrane analysis. In Geology of Ontario. P.C. Thurston, H.R. Williams, R.H. Sutcliffe, and G.M. Stott (Eds.). Ontario Geological Survey, Special Vol. 4, Part 1. pp. 81-144.
Stott, G.M. and Josey, S.D. 2009. Proterozoic mafic (diabase) dikes and other post-Archean intrusions of northwestern Ontario, north of latitude $49^{\circ} 30^{\prime}$; Ontario Geological Survey, Preliminary Map P.3606, scale 1:1 000000.

Tappe, S., Foley, S.F., Stracke, A., Romer, R.L., Kjarsgaard, B.A., Heaman, L.M., and Joyce, N. 2007. Craton reactivation on the Labrador Sea margins: ${ }^{40} \mathrm{Ar} /{ }^{39} \mathrm{Ar}$ age and $\mathrm{Sr}-\mathrm{Nd}-\mathrm{Hf}-\mathrm{Pb}$ isotope constraints from alkaline and carbonatite intrusives. Earth and Planetary Science Letters, 256, p. 433-454.

Wheeler, J.O., Hoffman, P.F., Card, K.D., Davidson, A., Sanford, B.V., Okulitch, A.V., and Roest, W.R. (compilation), 1996. Geological Map of Canada; Geological Survey of Canada, Map 1860A, scale 1:5000 000 .

Zentilli, M., Tremblay, A., Grist, A., 2001. Apatite fission track thermochronology of the Monteregian Hills and the Laurentian margin in southwestern Québec. Abstracts Geological Association of Canada Meeting, St. John's 26, p. 167. 